\title{
PRELIMINARY TESTS ON WINTER CEREAL VARIETIES OF RESISTANCE TO LOW TEMPERATURE PARASITIC FUNGI IN CONTROLLED CONDITIONS
}

\author{
H. H. Blomevist and E. A. Jamalainen \\ Department of Plant Pathology, Agricultural Research Centre, Tikkurila
}

Received February 15, 1968

In northern countries the cultivation of winter cereals is restricted by biotic as well as abiotic factors. The former group includes the low temperature parasitic fungi Fusarium nivale (Fr.) Ces., Typhula ishikariensis Imai and T. incarnata Lasch ex Fr., and, in certain instances in the northern parts of Scandinavia, also Sclerotinia borealis Bub. \& Vleugel. The damage caused by these fungi is considered particularly severe in years with deep snow cover or when snow has fallen on unfrozen soil (JAMALAINEN 1956); a snow cover of long duration is likewise believed to favour the injuries caused by the fungi (Potatosova 1960, BRuehl et al. 1966, Hänninen and Jamalainen 1968). A number of writers have, on the basis of field trials, shown differences in the resistance of winter cereal varieties to these parasitic fungi (Ekstrand 1947, 1955, Bruehl et al. 1964, Jamalainen 1964). Holton (1953) and Sprague (1961) found, however all the tested varieties highly susceptible to these pathogens.

The technique of carrying out tests of resistance to low temperature parasitic fungi under controlled conditions has been studied only to a relatively limited extent. WERNHAM and Hilton (1943) tested the resistance of winter cereals to Typhula spp.; no differences between the tested species could be shown, however. Cormack and Lebeau (1959) point out the practical value of such tests and describe a method which has since been modified (Sunderman 1964). Despite the fact that resistance tests carried out in laboratory and greenhouse conditions involve a number of difficult problems, results of studies made in recent years show that the method is usable and may, through continued application, be developed further (BRUEHL et al. 1966, BRUEHL 1967).

In the preliminary resistance tests described in this paper the methods of inoculation and analysis have been specially studied and the tested varieties of winter cereals are familiar from field trials. 


\section{Material and methods}

The infection material was increased in cool chambers in the laboratory $\left(8^{\circ} \mathrm{C}\right)$. Flat 1 litre flasks were used for the Typhula cultures, the medium consisted of a mixture of winter wheat kernels and distilled water autoclaved three times at intervals of 24 hours (Lemmann 1965). The method yields a large amount of infection material which compensates for the relatively long incubation period. The resulting sclerotia are easily separated from the medium after drying on filter paper. The inoculation was made with pure sclerotia as well as with a mixture of sclerotia, mycelium and medium.

$F$. nivale was increased on oat meal agar in Petri dishes and in the inoculation a homogenous suspension of the mixed contents in the dishes was used.

The following isolates were tested: $F$. nivale $1, T$. ishikariensis $1 \mathrm{a}, 1 \mathrm{~b}$ and 2 , and $T$. incarnata 1 . Isolates $1 \mathrm{a}$ and $1 \mathrm{~b}$ were in the form of pure sclerotia and differ only in that the first one was allowed to germinate in water before the inoculation. The two other Typhula isolates consisted of a mixture of sclerotia, mycelium and medium. The infection material dates from the spring of 1966 with the exception of $T$. ishikariensis la and b, which is older.

The shooting of the test plants was carried out in greenhouses. Seeds of three Finnish and three Swedish winter wheat and winter rye varieties were sown in 5 litre plastic pots in a fertilized mixture of humus and peat $(4: 1)$. At the start of the test each pot contained 80 plants, with three replicates to each variety. The mean temperature during the shooting period was $19^{\circ} \mathrm{C}$ and the mean humidity $61 \%$. The plants were given 8 hours of artificial light daily. After 14 days, when the development of the plants had reached a stage corresponding to normal winter shoots, the temperature was gradually lowered to $0^{\circ} \mathrm{C}$, which was made possible by the low temperature outside. The process of coldhardening lasted some 3 weeks and took place in an average temperature and humidity of $5{ }^{\circ} \mathrm{C}$ and $84 \%$, respectively, and in the same light conditions as above.

In the inoculation the plants were pressed down and the infection material was distributed evenly over the surface. The quantities per pot were: $0.5 \mathrm{~g}$ pure sclerotia, $50 \mathrm{ml}$ sclerotia, mycelium and medium, and $40 \mathrm{ml}$ Fusarium suspension. The pots were covered by regularly moistened cellulose wadding instead of snow (Fig. 1) and to prevent evaporation plastic sheets were used. During the incubation period the average temperature was $2{ }^{\circ} \mathrm{C}$ and the average humidity $87 \%$. The prevailing temperature is highly important at this stage as the resting condition of at least some varieties may become disturbed already at a temperature of $3-4^{\circ} \mathrm{C}$ (BRUEHL et al. 1966). Once the most susceptible winter cereal varieties were severely infected by the fungi the test was suspended and two preliminary visual analyses were made with one week's interval, and the amounts of mycelium, sclerotia and changes in colour were noted. Before the final analysis the plants were given two weeks to recover in conditions of normal light and temperature (Fig. 2).

\section{Results and discussion}

The control plants had a normal green colour when the test was suspended. In the inoculated pots, on the other hand, various kinds of severe injuries from the fungi were found in the form of dead plants, mycelium and sclerotia formation, and changes in colour. In the analyses of the three last named factors a scale of $0-4$ was used, $0=$ nothing visible, 


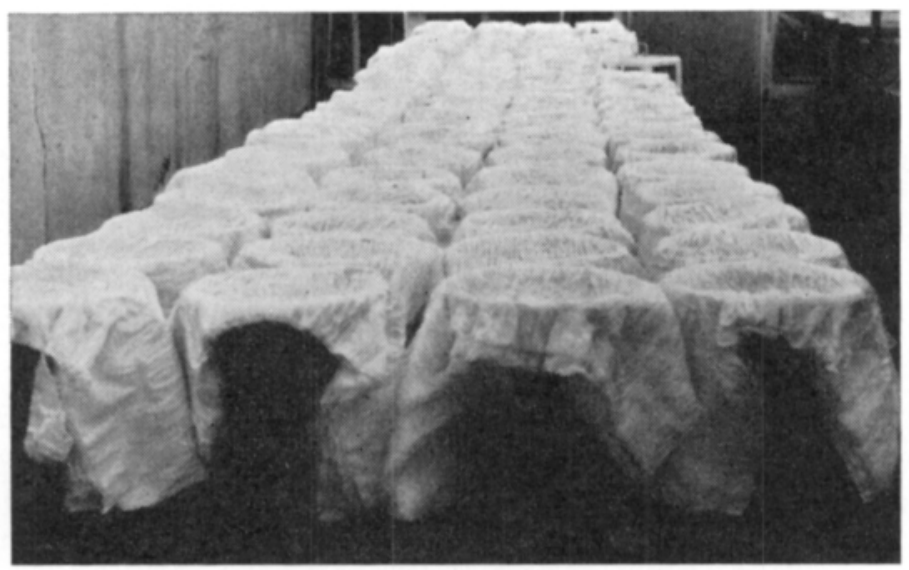

Fig. 1. After inoculation with fungi the pots were covered with regularly moistened cellulose wadding instead of snow and kept in an average temperature of $2^{\circ} \mathrm{C}$.

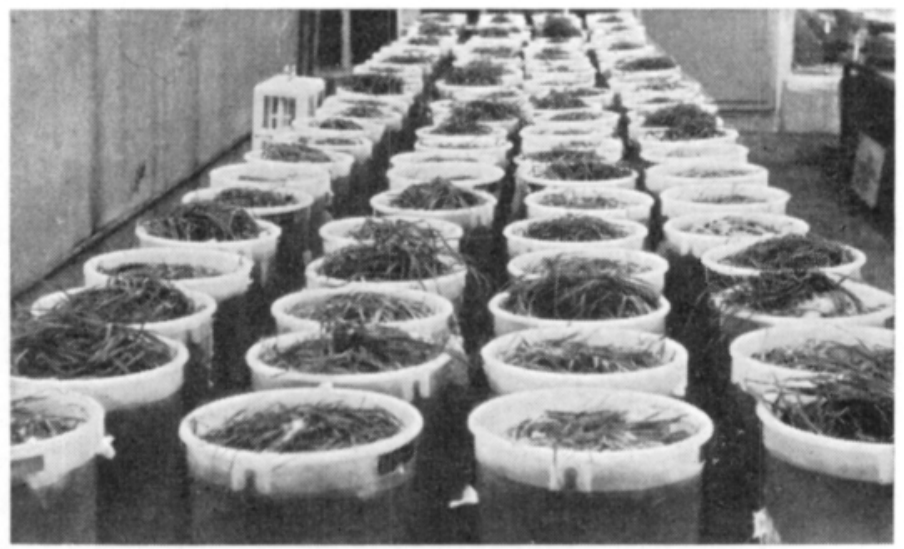

Fig. 2. Once the most susceptible varieties were severely infected by the fungi the covers were removed and the plants were allowed to recover for two weeks prior to being analyzed.

$4=$ very severe damage. The results are presented in Table 1 . The table shows that compared with the winter wheat varieties there was abundant Fusarium mycelium in winter rye (see also Fig. 3a). There were also differences in mycelium formation between the different varieties of winter rye. Changes in colour in the form of spotted or yellowed leaves were clearly discernible in the first analysis $\left(\mathrm{f}_{1}\right)$, but these vanished to a great deal, however, when the plants recovered $\left(\mathrm{f}_{2}\right)$, which indicates that the real injuries need in this case not be as severe as they may seem at first sight. The different Typhula isolates, on the other hand, caused in winter wheat more lasting changes, which in many cases might even increase during the recovery period (Fig. 3b, c). Similar developments have also been noted in field analyses in the spring. The formation of mycelium did not appear to differ much in the different varieties. 
Table 1. Visual analyses according to scale $0-4$ of winter cereal varieties infected with $F$. nivale, $T$. ishikariensis and $T$. incarnata. $\mathrm{m}=$ mycelium, $\mathrm{f}=$ changes in colour, $\mathrm{s}=$ sclerotia formation; $0=\mathrm{no}$ visible damage, $4=$ richly fungal structures.

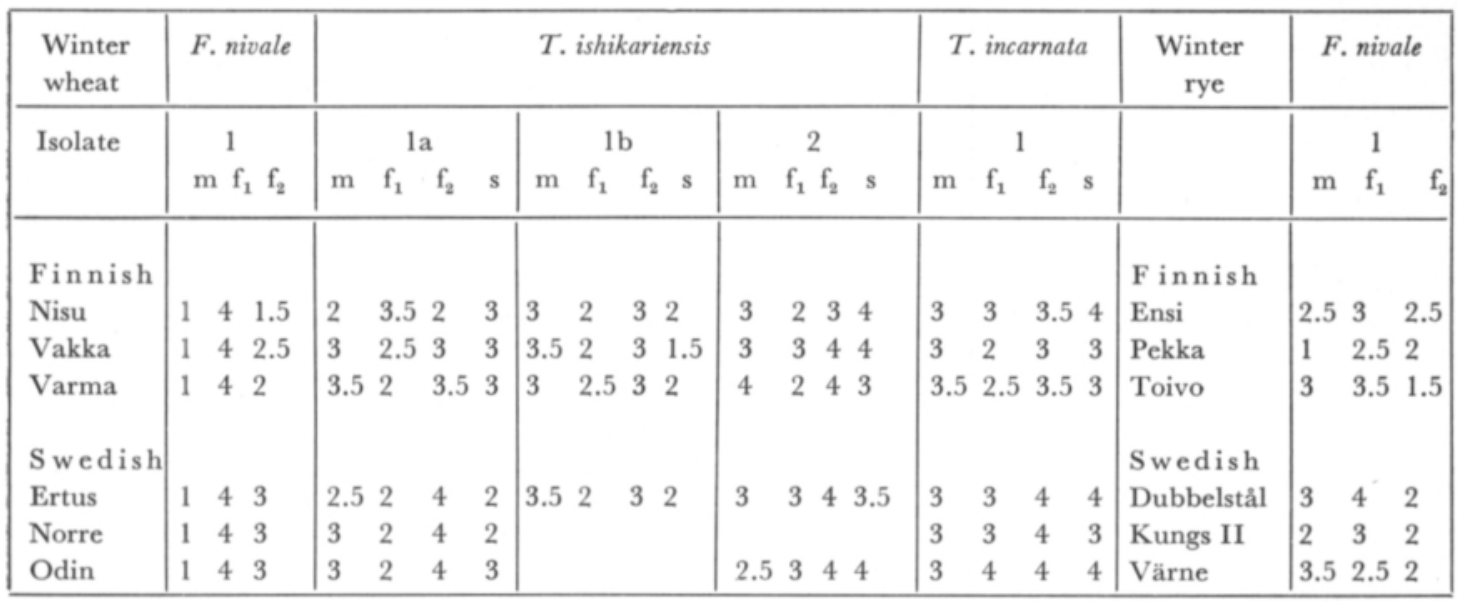



a



b



c
F:g. 3. Damage on winter cereals caused by $F$. nivale and $T$. ishikariensis:

a) F. nivale on Swedish winter rye Dubbelstål

b) T. ishikariensis on Finnish winter wheat Varma

c) $T$. ishikariensis on Swedish winter wheat Odin (control left) 
Table 2. Number of surviving plants (\%) and their mean length $(\mathrm{cm})$ in infection of winter cereal varieties with $F$. nivale, $T$. ishikariensis and $T$. incarnata.

\begin{tabular}{|c|c|c|c|c|c|c|c|c|c|}
\hline \multirow{2}{*}{$\begin{array}{l}\text { Winter } \\
\text { wheat }\end{array}$} & \multirow[t]{2}{*}{$F$. nivale } & \multicolumn{5}{|c|}{ T. ishikariensis } & \multirow{2}{*}{$\begin{array}{c}\begin{array}{c}T \text {. incar- } \\
\text { nata }\end{array} \\
1\end{array}$} & \multirow{2}{*}{$\begin{array}{l}\text { Winter } \\
\text { rye }\end{array}$} & \multirow{2}{*}{$\frac{F \text { nivale }}{1}$} \\
\hline & & $1 \mathrm{a}$ & & $1 b$ & 2 & & & & \\
\hline Finnish & & & & & & & & Finnish & \\
\hline Nisu & $92 \quad 15.7$ & 6011.2 & 88 & 14.4 & 22 & 9.2 & $\begin{array}{ll}67 & 13.1\end{array}$ & Ensi & $\begin{array}{ll}79 & 13.9\end{array}$ \\
\hline Vakka & $\begin{array}{ll}96 & 15.7\end{array}$ & 6213.4 & 95 & 14.4 & 39 & 12.6 & $\begin{array}{ll}70 & 14.9\end{array}$ & Pekka & $86 \quad 16.1$ \\
\hline Varma & 9614.5 & $48 \quad 11.8$ & 74 & 13.1 & 25 & 9.1 & 4611.6 & Toivo & $\begin{array}{ll}77 & 14.8\end{array}$ \\
\hline Swedish & & & & & & & & Swedish & \\
\hline Ertus & $92 \quad 14.6$ & $\begin{array}{ll}46 & 10.7\end{array}$ & 79 & 13.5 & 24 & 9.0 & $40 \quad 13.4$ & Dubbelstål & $\begin{array}{ll}77 & 14.1\end{array}$ \\
\hline Norre & $\begin{array}{ll}86 & 14.7\end{array}$ & $45 \quad 10.9$ & & & & & 3312.1 & Kungs II & $\begin{array}{ll}68 & 13.2\end{array}$ \\
\hline Odin & $88 \quad 15.2$ & 2511.1 & & & 8 & 6.4 & $\begin{array}{ll}36 & 11.3\end{array}$ & Värne & $\begin{array}{ll}65 & 13.8\end{array}$ \\
\hline
\end{tabular}

In the final analysis the surviving plants were counted and measured (Table 2). In the control pots the plants were in all instances longer than in the inoculated ones. The results show that there is a correlation between the degree of injury and the length in the surviving plants. $F$. nivale, which was more pathogenic to winter rye than to winter wheat varieties (cf. Table 1), caused only minor injuries to winter wheat when compared to the two Typhula species. The sclerotia that had been subjected to water treatment (1a) were more effective as infection material than the dry ones (1b) and had presumably more advantageous starting points at the beginning of the incubation period. The most severe damage, however, was caused by isolate 2 .

The limited amount of material used in these preliminary tests does not permit a critical comparison of resistance to $F$. nivale, $T$. ishikariensis and $T$. incarnata although clear variations do exist between the different varieties. As has been stated, the injuries caused by $F$. nivale were more severe in winter rye than in winter wheat, which is in agreement with the fact that in natural conditions this fungus as a rule causes more severe damage on winter rye (Jamalainen 1956, 1964). The difference between the tested varieties was, however, not significant. This does not necessarily mean that there would be no variety resistance since the isolate may prove to be relatively nonvirulent and to need a long incubation period to produce significant results.

The two Typhula species caused severe injuries to the tested winter wheat varieties and were considerably more aggressive than $F$. nivale. There were clear differences in resistance in the tested varieties. The weak pathogenity of $T$. ishikariensis isolate 1 compared to 2, may be due to the fact that the first mentioned isolate, which had been kept in laboratory conditions for a longer period, had possibly lost some of its original virulence; this point has not been confirmed, however (BRUEHL et al. 1966). The variation may also be due to the inoculation method used. The injuries caused by $T$. incarnata were not as severe as those caused by $T$. ishikariensis isolate 2 , a point which has also been noted earlier (BRUEHL 1967). BRUEHL likewise shows that a correlation exists in the resistance of tested winter wheat varieties to the three low temperature fungi, a fact indicated also by the results in Table 2. 
The degree of effectivity in the methods of inoculation may likewise vary. An effectivemethod and suitable infection material enable a shortening of the often relatively long period of incubation. In the inoculation process a mixture of fungus material and growing medium has often been applied (Cormack and Lebeau 1959, Sunderman 1964). Inoculation with pure fungus material may, however, be as effestive.

The colour changes in Table 1 may prove of practical value. The final analyses of field trials with low temperature parasitic fungi should not be made too early in the spring since plants injured by $F$. nivale may recover, while others, injured by Typhula spp. die only after some time has elapsed.

In field trials arranged in the course of several years in different parts of the country, Finnish winter wheat and winter rye varieties have overwintered much more successfully than the corresponding Swedish ones (Jamalainen 1964). Ensi- and Toivo- winter rye have shown greater resistance to $F$. nivale than Pekka, while the Swedish varieties have been considerably more susceptible to the injuries of this fungus (Fig. 3a). Correspondingly, the winter wheat varieties Vakka and Varma have shown themselves more resistant to Typhula fungi than the Swedish variety Ertus (Fig. 3b, c). The results in Table 2 likewise show that the Finnish winter cereal varieties have proved more resistant than the Swedish to the low temperature parasitic fungi. In these trials the winter rye Pekka exhibited the highest degree of resistance to $F$. nivale and the winter wheat Vakka to this fungus as well as to $T$. ishikariensis and $T$. incarnata.

Further trials are going to show the usefulness of the method described above in the testing of the resistance of winter cereal varieties to low temperature parasitic fungi in controlled conditions. It should be possible, on the basis of such trials, to show which breeds are so highly susceptible to these fungi that they may be excluded from further studies.

\section{S u m m a ry}

The present work describes a method for the testing of the resistance of winter cereal varieties to Fusarium nivale, Typhula ishikariensis and T. incarnata.

The shooting of the plants was carried out in greenhouses and after a period of 3 weeks of coldhardening the plants were infected, covered with cellulose wadding and placed in a temperature of $2^{\circ} \mathrm{C}$. Once the varieties with the highest susceptibility were severely infected by the fungi the test was suspended and the plants were given some 2 weeks to recover prior to being analysed. The tested varieties were well known from field trials during a number of years. The results agree in the main with those obtained in the field. The Finnish winter wheat and winter rye varieties showed a greater degree of resistance to the above fungi than the Swedish ones. The injury inflicted by $F$. nivale on winter rye was more severe than that on the winter wheat varieties. $T$. ishikariensis and $T$. incarnata were considerably more pathogenic to wheat than $F$. nivale, and the tested varieties showed varying degrees of resistance to these fungi. The results likewise point to a correlation existing in the resistance to the three low temperature parasitic fungi.

Financial support for these studies has been received from the State Scientific Committees. in Denmark, Finland, Norway and Sweden. 


\title{
REFERENCES
}

Bruehl, G. W., Fischer, W. R. and Nagamitsu, M. 1964. Resistance to snow mold of winter wheat. (Abstr,) Phytopath. 54: 1432.

-,- - Sprague, R., Fischer, W. R., Nagamitsu, M., Nelson, W. L. and Vogel, O. A. 1966. Snow molds of winter wheat in Washington. Wash. Agric. Exp. Sta., Coll. of Agric., Wash. State Univ., Bull. 677: 1-21.

-, - 1967. Correlation of resistance to Typhula idahoensis, T. incarnata and Fusarium nivale in certain varieties of winter wheat. Phytopath. 57: 308-310.

Cormack, M. W. and Lebeau, J. B. 1959. Snow mold infection of alfalfa, grasses, and winter wheat by several fungi under artificial conditions. Can. J. Bot. 37: 685-693.

EKstrand, H. 1947. Några växtpatologiska synpunkter på övervintringen av höstsäd och vallgräs, med särskild hänsyn till försöksverksamheten inom jordbruket. Medd. Växtskyddsanst. 49: 1—48, Stockholm.

—,-— 1955. Höstsädens och vallgräsens övervintring. Sammanfattning av hittills utförda och program för fortsatta undersökningar. Ibid. 67: 1-125.

Holton, C. S. 1953. Observations and experiments on snow mold of winter wheat in Washington State. Pl. Dis. Rep. 37: 354-359.

Hänninen, P. and Jamalainen, E. A. 1968 a. Syysviljojen talvehtiminen Keski-Suomessa. I. Syysvehnä. Summary: Overwintering of cereals in Middle Finland. I. Winter wheat. Ann. Agric. Fenn. 7. In print.

-,_- 1968 b. Syysviljojen talvehtiminen Keski-Suomessa. II. Syysruis. Summary: Overwintering of cereals in Middle Finland. II. Winter rye. Ibid. 7. Inprint.

Jamalainen, E. A. 1956. Overwintering of plants in Finland with respect to damage caused by lowtemperature pathogens. Publ. Finn. State Agric. Res. Board 148: 5-23.

-,-, 1964. Control of low-temperature parasitic fungi in winter cereals by fungicidal treatments of stands. Ann. Agric. Fenn. 3: 1-54.

Lehmann, H. 1965. Untersuchungen über die Typhula-Fäule des Getreides. I. Zur Physiologie von Typhula incarnata Lasch ex Fr. Phytopath. Z. 53: 255-288.

Potatosova, E. G. 1960. Typhulosis on winter crops (Russ.). Trud. Vses. Inst. Zashch. Rast. 14: 135 -142.

Sprague, R. 1961. Epidemiology and control of snow mold of winter wheat and grasses in the Pacific Northwest of the United States. Rec. Adv. in Bot., Sect. 5: 540-544. Univ. Toronto Press.

Sunderman, D. W. 1964. Modifications of the Cormack and Lebeau technique for inoculating winter wheat with snow mold-causing Typhula species. Pl. Dis. Rep. 48: 394-395.

Wernham, C. C. and Chilton, St. John P. 1943. Typhula snowmold of pasture grasses. Phytopath. 33: $1157-1165$.

\section{SELOSTUS}

\section{ALUSTAVAT, KONTROLLOIDUISSA OLOSUHTEISSA SUORITETUT KOKEET SYYSVILJALAJIKKEIDEN TALVITUHOSIENI-KESTÄVYYDESTÄ}

\author{
H. H. BlomQvist ja E. A. Jamalainen \\ Kasvitautien tutkimuslaitos, Tikkurila
}

Artikkelissa on kuvattu menetelmä, jolla tutkittiin syysruis- ja syysvehnälajikkeiden kestävyyttä Fusarium nivalea, Typhula ishikariensista ja $T$. incarnataa vastaan.

Kokeet suoritettiin kasvihuoneessa. Koekasvien orastumisen jälkeen kasvit karkaistiin vähitellen alenevissa lämpötiloissa, infektoitiin sienien puhdasviljelyksillä, peitettiin selluloosavanulla (kuva 1) ja sijoitettiin talvehtimaan $+2^{\circ} \mathrm{C}$ asteen lämpötilaan. Koe keskeytettiin silloin kun altteimmat lajikkeet olivat pahasti sienten saastuttamia, ja kasvien annettiin olla ennen analysointia toipumassa n. kaksi viikkoa 
korkeammassa lämpötilassa. Kokeissa olleiden vehnä- ja ruislajikkeiden (taulukko 1 ja 2) suhtautuminen talvituhosieniin on tunnettu monivuotisten kenttäkokeiden perusteella. Lajikkeiden alttius talvituhosienille oli kasvihuonekokeissa suurimmaksi osaksi samantapainen kuin kenttäkokeissa. Suomalaiset syysvehnä ja syysruisjalosteet olivat kstävämmät kokeiltavana olleita sieniä vastaan kuin ruotssalaiset. $F$. nivalen aiheuttamạt vauriot olivat syysruislajikkeissa pahemmat kuin syysvehnälajikkeissa. T. ishikariensis ja $T$. incarnata olivat vehnälle huomattavasti patogenisempia kuin $F$. nivale. Eri lajikkeiden kestävyys Typhulasieniä vastaan oli vaihteleva. Kokeet osoittivat että syysviljalajikkeiden kestävyydessän kokeiltavana olleita sieniä vastaan on olemassa korrelaatio. 